\title{
REGIONAL DIFFERENCES IN THE LABOUR MARKET IN SLOVAKIA AND THE CZECH REPUBLIC
}

\author{
- Eva Koisova, Jana Masarova, Jozef Habanik
}

\begin{abstract}
At present, Slovakia and the Czech Republic are experiencing favourable economic conditions. The socio-economic development in regions in the country except a new created product is also affected by labour market factors, employment and average salary. This paper assesses and compares the development trends in employment and average wages in the regions of Slovakia and the Czech Republic, and defines development differences over a selected time period: 20072016. We used statistical indicators to monitor the observed phenomenon variability by means of setting the minimum, maximum and average variation ranges and coefficients. To set a position, from descriptive characteristics a simple arithmetic mean was used. From the results of the analyses, it can be seen that significant regional differences exist in the Czech and Slovak labour markets due to different primary potentials, different possibilities of development, economic structures, demographic differences and levels of infrastructure. The situation in the Czech labour market is better than in Slovakia, and the differences among regions are smaller in the Czech Republic. For the particular regions, we chose territorial units at the NUTS III level.
\end{abstract}

Keywords: regional differences, labour market, employment, average wages, Cžech Republic, Slovakia JEL Classification: J31, J21, R11

\section{INTRODUCTION}

The region is a basic unit that is both internally and externally interlinked. Each region also has specific characteristics and features, which influences its development trends. This ultimately leads to uneven economic development and activity, and regional disparities. This happens because there are differences in natural-geographic conditions that are not equally favourable to all economic activities, and humans are consciously affecting the deployment of these activities (Pietrzak, et al., 2017; Pavlova \& Šenfelde, 2017; Cheba et al., 2017).

In this paper, we assess and compare the development trends in employment and average wages in the regions of Slovakia and the Czech Republic, and define development differences over a selected time period. The theoretical section provides an overview of the issue of employment and average wages. Then the aims, data and applied methodology are presented. In the analysis section, we present the actual situation in the area of employment and average wages in the regions of Slovakia and the Czech Republic. The last section concludes the paper and mentions the main findings. 


\section{THEORETICAL BACKGROUND}

Labour market issues in Slovakia are relatively attractive topics from the point of view of regional development, and disparities and have been observed by, e.g., Szekely (2001) and Bezák (2001). Grenčíková \& Španková (2016) are directly concerned with the issue of differences in the labour market. The regional income inequalities of social groups in Slovakia and their impact on social classes and poverty were examined by Michálek (2010), and the income stratification was detailed by Pauhofová (2010). The topic of regional disparities in the Czech Republic is also important for authors such as Měrtlová (2012), or Svatošová \& Novotná (2012). The issue of impact of foreign direct investment on the labour market in the Czech Republic was described by Baštová \& Dokoupil (2010).

The labour market is working with the most precious capital of economy, and that is human capital, which is also the carrier of labour. Labour is one of the most important production factors because it contributes to the economic growth of a state or region (Androniceanu \& Ohanyan, 2016; Simionescu et al., 2016; Cyrek, 2017; Ohanyan \& Androniceanu, 2017; Sanusi, et al., 2017). According to Kordoš \& Vojtovič (2016), it is being estimated that supranational organizations directly employ $4 \%$ of total employment in developed countries and $12 \%$ of all employees in developing countries. The accession of the Slovak Republic and the Czech Republic to EU but also important reforms that both countries had to undertake in the first half of this decade along with the world economic boom have brought a significant inflow of foreign direct investments into these countries. It has influenced their labour market development and contributed to the reduction of unemployment. The level and quality of labour force began to contribute to gradual position improvement of Slovak and Czech enterprises within the group networks and to an increase in production sophistication. In this context, the wage, which is defined as labour cost, plays an important role. Wage as a work remuneration has a different meaning for an employer and other for employee (Pernica, 2017). However, most people see it as work remuneration, being the main source of their income and an important indicator of living standard.

Nevertheless, wages are also an important macroeconomic indicator that affects the growth of consumption in the economy. From the macroeconomic point of view, increasing wages contribute to increasing revenues and, at the same time, to increasing consumption and investments demand. On the other hand, Blecker (2016) argues that higher labour costs may diminish the competitiveness of national products, thereby reducing net exports, and can also lessen the profits that are one of the main incentives (or financial sources) for private investment.

Work remuneration has always been a sensitive point of interest between the employer and employee. It is interesting to note that the results of mutual interests have not been left exclusively on the invisible hand of market, but the consensus has been implemented into a normative remuneration regulation (especially at national level but to some extent also at international level) to ensure a minimum level of social well-being for an employee by respecting the employer's economic power (Dolobáč, 2013). The level of wages in Slovakia and availability of cheap workforce were one of the main factors for the income of foreign investors. Human capital being attracted by investors does not only meet the function of labour force, but as Krajňáková (2014) states, it is also the most valuable and most important economic means of society and is the main factor of economic growth and an important source of competitive advantage. Also, managing 
human capital by transformational leaders (Bratianu \& Anagnoste, 2011) contributes to achieving a competitive advantage (Dragolea, et al. 2017). Wage is created in the labour market and its height is derived from demand, respectively, job offers. On the other hand, a successful adaption of employees to the firm's requirement is also one of the HR management key activities (Stacho et al., 2017).

Labour supply is also influenced by the rate of unemployment, respectively, employment. A rise in the effective average corporate tax rate significantly increases unemployment levels (Zirgulis \& Šarapovas 2017). Ivanová et al. (2006) indicates that employment is directly related to population that is active. Then, when talking about employment, we mean the ratio of the number of employed people to the number of all working-age population. The employment rate is considered to be a key social indicator and is used for analytical purposes to investigate the labour market development. Thus, the employment rate is calculated as the ratio of the number of working people (over 15 years of age) to the total population over 15 years of age. The employment rate can be expressed by the following relationship:

employment rate $(\%)=$ (number of persons over 15 years of age $) /($ population over 15 years of age $) \times 100$

Employment has a positive impact not only on macroeconomic indicators but also on regional development (Gavurova et al., 2017). Some studies show that employment influences to a large extend people's commitment to community development and correlates with inclusiveness of a nation (Păunescu et al., 2017). Empirical studies show that employment is also an important social indicator for the development of society and the personality of human being, especially in terms of young people. On the other hand, according to the research done by Vancea \& Utzet (2017), youth unemployment has undesirable behaviour; because mainly unemployed young people tend to have health problems. This negative effect is manifested even though young people are working in precarious conditions. In addition, researches on the labour market have been carried out, which observed how employment is being transformed from one sector (mining) to another (services, construction, retail, transport, etc.) and their effects on the labour market (Komárek, 2016).

\section{AIM, METHODOLOGY AND DATA}

The goal of the paper is to assess the development trends in employment and average wages in the regions of Slovakia (SR) and the Czech Republic (CR), their mutual comparison and to define development differences in selected time series. The primary criteria for the survey are employment and average wages.

To achieve the goal, statistical methods and analyses of investigated phenomena and relevant data comparison of each category within the observed criteria of both economies were used. We monitored the development of employment and average nominal wage in Slovakia and the Czech Republic.

We used statistical indicators to monitor the observed phenomenon of variability by means of setting the minimum, maximum, average, variation range and variation coefficient. To set a position, from descriptive characteristics, a simple arithmetic mean was used, being described by the following relationship: 


$$
\bar{x}=\frac{1}{n} \sum_{i=1}^{n} x_{i}=\frac{\sum_{i=1}^{n} x_{i}}{n}
$$

Where $\mathrm{n}$ - the number of observations,

$$
\begin{aligned}
& i=1,2,3 \ldots n, \\
& \sum n_{i}=n .
\end{aligned}
$$

To find out how the values in statistics file are similar or different, we determined the variability degree by means of a variation range:

$$
\mathrm{R}_{v}=x_{\text {max }}-x_{\text {min }}
$$

The variation coefficient is used to compare the variability of files with different diameters and is set as:

$$
v_{x}=s / \bar{x}
$$

Where $\bar{x}$ - average, $s$ - standard deviation, while the „s“ is set as follows:

$$
s=\sqrt{s^{2}}=\sqrt{\frac{\sum_{i=1}^{n}\left(x_{i}-\bar{x}\right)^{2}}{n}}
$$

The research is carried out through relevant data analyses on employment and wages; next, to compare the individual categories within the observed criteria, the method of comparison, and to find out differences, the method of synthesis was used. The methods of induction and deduction were used to assess and generalize our conclusions. As a relevant data base, the database of the Statistical Office of the Slovak Republic (SO SR) and the Czech Statistical Office (CZSO) were used.

\section{EMPLOYMENT IN THE REGIONS OF SLOVAKIA AND THE CZECH REPUBLIC}

Employment can be defined as involvement of working people in the process of creating new products and services. Employment has a direct impact on a created product, ergo, on economic and social developments in a state and individual regions. It refers to labour market flexibility. Employment trends, as stated above, are observed by the employment rate indicator, i.e. the share of number of people being employed over 15 years of age on the total population older than 15 years of age, expressed in percentage.

\subsection{Employment rate evolution in the regions of Slovakia}

In the Slovak Republic, there are significant differences in the economic level of individual regions, being closely related to differences in the labour market, along with employment. The evolution of employment rate of persons over 15 years of age in the regions of Slovakia in 20072015 is shown in Figure 1. 
From a graphical representation, it is possible to observe the distinctive differences among employment rates in the regions of Slovakia. In the observed period of 2007-2014, the highest employment level was in the pre-crisis period (2008) when the economic recession employment decreased in all regions of SR. Since then, it only increased slightly.

The highest employment rate was during the whole observed period in the Bratislava Region ranging from $62.9 \%$ in 2008 up to $59.5 \%$ in 2010 . The second best region within the employment level is the Trnava Region, Trenčín Region is still holding above the Slovak average. The lowest rate of employment is recorded by the Košice Region, except in 2009 (Banská Bystrica Region) and in 2015 (Prešov Region). Regarding the year-on-year employment rate development in individual regions, during the pre-crisis period the highest employment growth was achieved by the Nitra region, in 2007 with the growth of 2.4 p.p., in 2008 of 2.5 p.p. On the other hand, this region also reached the largest drop in the employment rate in 2009 by 4.1 p.p. The Banská Bystrica Region as the only one recorded the employment growth already in 2010, other regions in the following years, the Trnava Region not until 2015.

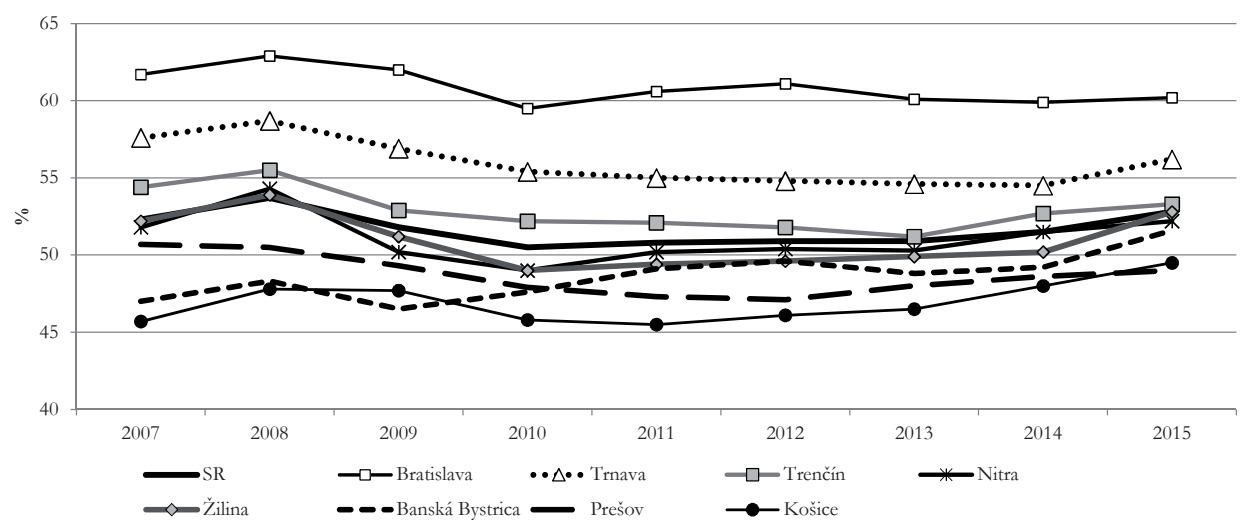

Fig. 1 - Employment rate in the regions of the Slovak Republic (\%). Source: own processing based on the Statistical Office of the SR data

\subsection{Employment rate evolution in the regions of the Czech Republic}

Regional differences among the regions of the Czech Republic can also be seen in the values of employment rate indicator. In 2007-2015, the employment rate in the Czech Republic was developing changeably, as shown in Figure 2. 


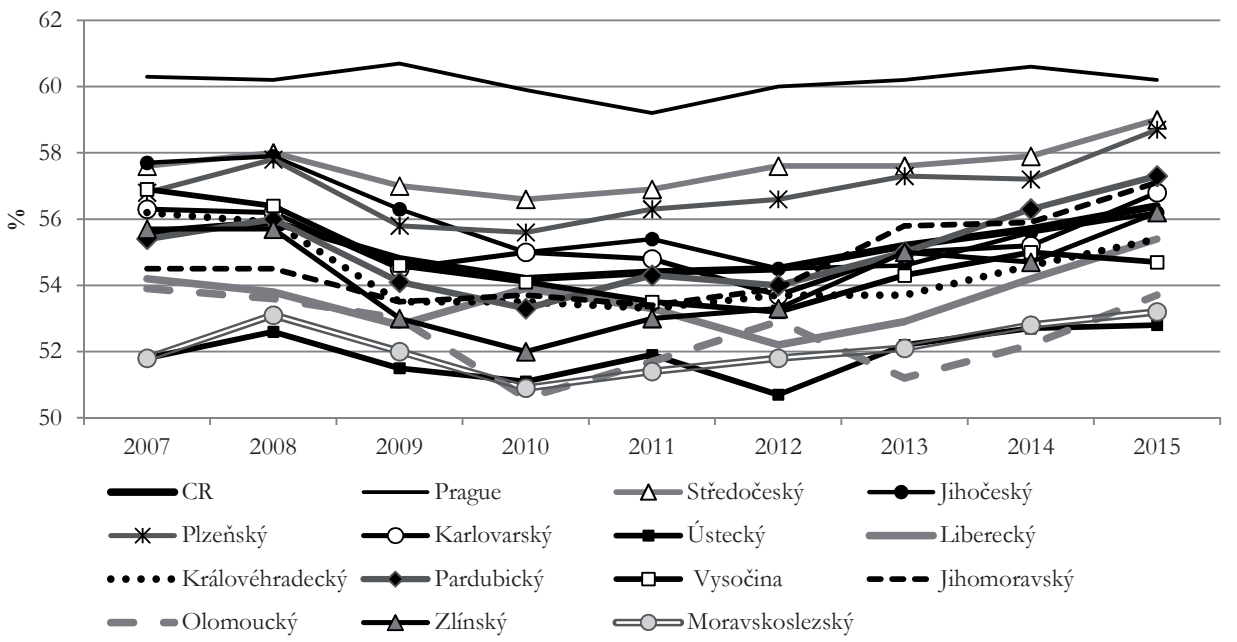

Fig. 2 - Employment rate in the regions of the Czech Republic (\%). Source: own processing based on the Czech Statistical Office data

In the Czech Republic as well as in Slovakia, there are significant differences in employment rates in individual regions. In the period reviewed, the employment rate development was fluctuating with an increasing tendency. The highest employment rate is recorded by the capital city of Prague, up to $60.7 \%$ in 2009. Between the capital city of Prague and other regions, there is a large gap, which was reduced only later; since the employment fell in Prague, while in other regions, it grew. Regions with the lowest level of employment include the Ústecký, Olomoucký and Moravskoslezský Regions.

In 2009, in all regions, with the exception of Prague, employment was decreasing, in most regions, employment was declining also in 2010, in six regions it was falling in 2011 and also in 2012. The largest drop in the employment rate was registered in the Zlín Region in the year 2009 (a decrease by 2.7 p.p.). On the contrary, the rate of employment increased the most in the Jihomoravský Region in 2013 (by 1.9 p.p.).

\subsection{Employment trends comparison in the regions of Slovakia and the Czech Republic}

We compared the employment trends in the regions of Slovakia and the Czech Republic by means of indicators: minimum, maximum, average, variation range and variation coefficient. The values of these indicators are shown in Table 1. 
Tab. 1 - Employment rates differences in the regions of SR and the Czech Republic. Source: own calculations

\begin{tabular}{|c|c|c|c|c|c|c|c|c|c|}
\hline & 2007 & 2008 & 2009 & 2010 & 2011 & 2012 & 2013 & 2014 & 2015 \\
\hline \multicolumn{10}{|c|}{ Slovak Republic } \\
\hline minimum & 45.7 & 47.8 & 46.5 & 45.8 & 45.5 & 46.1 & 46.5 & 48.0 & 49.0 \\
\hline maximum & 61.7 & 62.9 & 62.0 & 59.5 & 60.6 & 61.1 & 60.1 & 59.9 & 60.2 \\
\hline average & 52.3 & 53.7 & 51.8 & 50.5 & 50.8 & 50.9 & 50.9 & 51.5 & 52.8 \\
\hline $\begin{array}{l}\text { variation } \\
\text { range }\end{array}$ & 16.0 & 15.1 & 15.5 & 13.7 & 15.1 & 15.0 & 13.6 & 11.9 & 11.2 \\
\hline $\begin{array}{l}\text { variation } \\
\text { coefficient }\end{array}$ & 9.43 & 9.00 & 9.28 & 8.54 & 8.80 & 8.78 & 7.96 & 7.13 & 6.46 \\
\hline \multicolumn{10}{|c|}{ Czech Republic } \\
\hline minimum & 51.8 & 52.6 & 51.5 & 50.6 & 51.4 & 50.7 & 51.2 & 52.2 & 52.8 \\
\hline maximum & 60.3 & 60.2 & 60.7 & 59.9 & 59.2 & 60.0 & 60.2 & 60.6 & 60.2 \\
\hline average & 55.6 & 55.9 & 54.8 & 54.2 & 54.4 & 54.5 & 55.2 & 55.2 & 56.4 \\
\hline $\begin{array}{l}\text { variation } \\
\text { range }\end{array}$ & 8.5 & 7.6 & 9.2 & 9.3 & 7.8 & 9.3 & 9.0 & 8.4 & 7.4 \\
\hline $\begin{array}{l}\text { variation } \\
\text { coefficient }\end{array}$ & 4.01 & 3.74 & 4.21 & 4.42 & 3.87 & 4.31 & 4.23 & 3.86 & 3.76 \\
\hline
\end{tabular}

It is clear from Table 1 that in the Slovak Republic, the minimum employment rate values are lower than in the Czech Republic, the largest difference is in 2008, up to 6.1 p.p.; the smallest difference is in 2015, it is 3.8 p.p. The highest employment rate value in the Slovak Republic is higher than in the Czech Republic in most years (with the exception of 2010, 2013 and 2014). It is implied that the variation range is higher in SR (in 2007 and 2008 up to 7.5 p.p.), but the difference between SR and the Czech Republic decreased up to 3.8 p.p. in 2015.

The development of employment rate variation coefficient in the regions of Slovakia and the Czech Republic is shown in Figure 3.

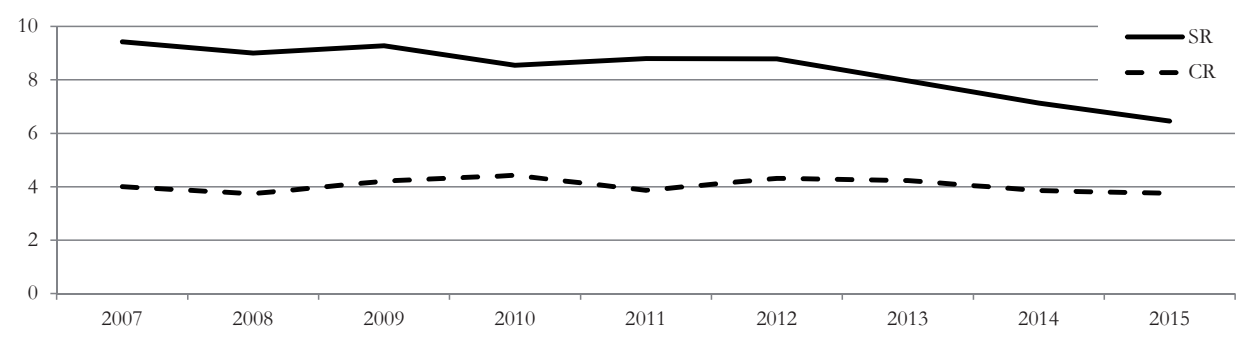

Fig. 3 - Employment rate variation coefficient. Source: own processing, own calculations

As it can be seen from Figure 3, the Slovak Republic has a significantly higher variability in the employment rate level in individual regions (in 2008 to 9.42) compared to the Czech Republic. 
However, the differences among regions were gradually decreasing since 2012. In the Czech Republic, the variation coefficient is lower and it remains relatively stable, ranging from 3.74 in 2008 up to 4.42 in 2010. Differences among the regions of the Czech Republic are therefore lower and the variability does not change significantly.

\section{THE AVERAGE MONTHLY WAGE IN THE REGIONS OF SLOVAKIA AND THE CZECH REPUBLIC}

When observing labour market developments, the average wage indicator appears to be significant. The average monthly wage represents the average level of gross wages in national economy. However, it is a relative concept, its representativeness is reduced by extreme values (e.g. too high wages of some employees' groups).

\subsection{Average monthly wage evolution in the regions of Slovakia}

Wage development is closely linked to economic development, inflation rate and labour productivity growth. The average monthly wage development in the regions of Slovakia in 2007-2015 is shown in Figure 4.

It can be seen in Figure 4 that in the period observed, the wages in Slovak regions were growing; a slight decline was recorded only by the Nitra Region in 2012. The only region where the average monthly wage is higher than the Slovak average is the Bratislava Region. It is implied that wages in the Bratislava region increase the Slovakia's average wage because average wages in other regions do not reach the average wage level in SR. The gap between the Bratislava Region and other regions is even increasing. Other regions achieved the highest average wage in the Trnava and Košice Regions. In the last three years, the employees from the Trenčín Region achieved the highest average wage. The lowest average wages are in the Prešov Region.

In terms of the wage growth, it was growing significantly faster in the pre-crisis period. In 2008, wages were rising mostly in the Nitra, Žilina and Prešov Regions, by almost 10\%. The highest absolute increase was in 2008 in the Bratislava Region (by EUR 67). Since 2009, wages were growing significantly slower; the situation improved only in the last two years.

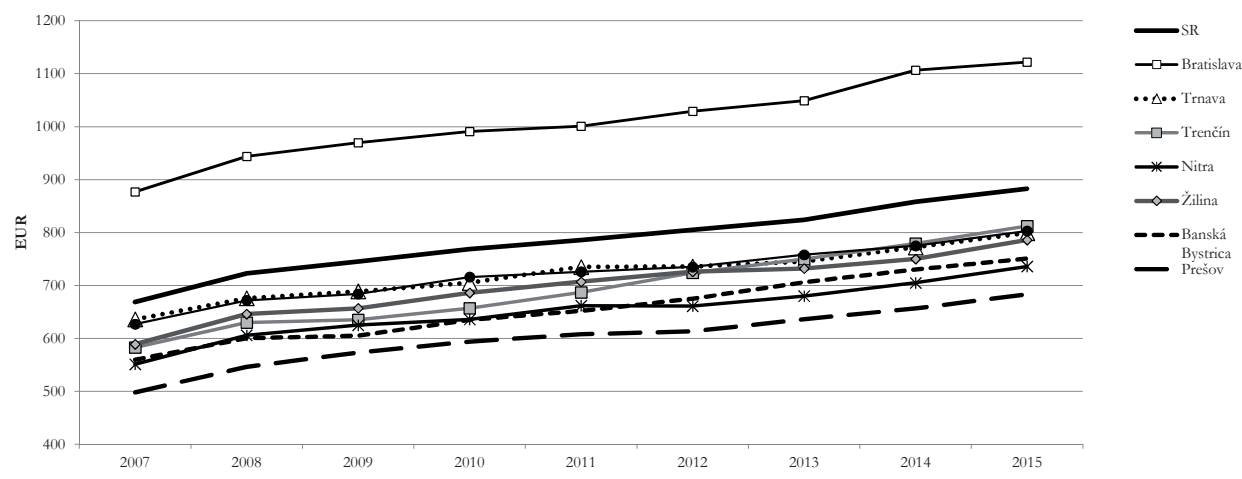

Fig. 4 - Average monthly wages in the regions of the Slovak Republic (EUR). Source: own processing based on the Statistical Office of the SR data 


\subsection{The average monthly wage evolution in the regions of the Czech Republic}

The average monthly wage in the regions of the Czech Republic in the observed period of 20072015 had an increasing trend, as shown in Figure 5.

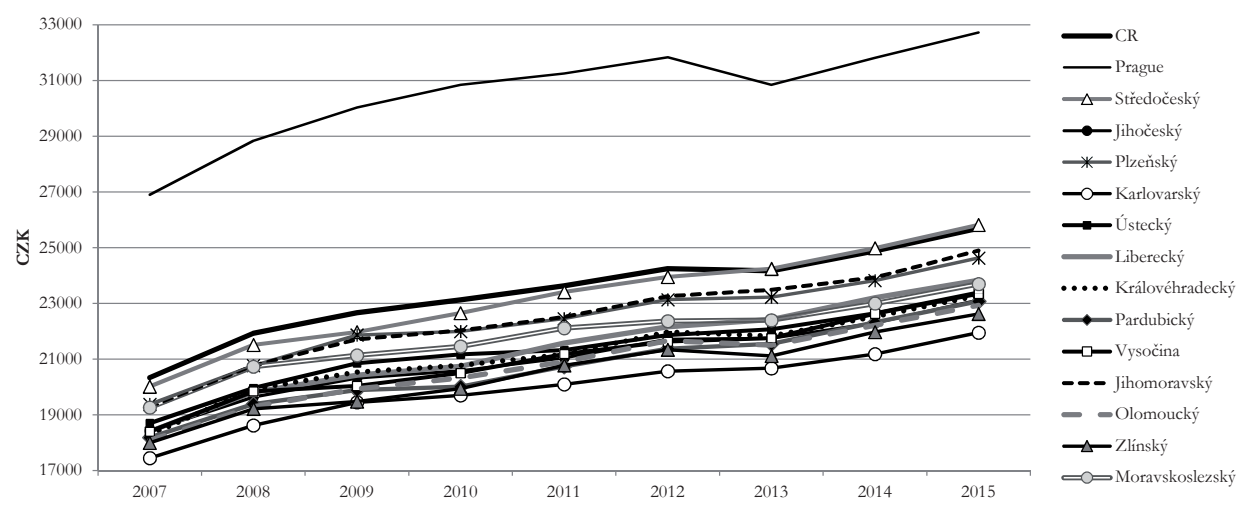

Fig. 5 - Average monthly wage in the regions of the Czech Republic (CZK). Source: own processing based on the Czech Statistical Office data

The same situation is in Slovakia. Regarding the average wage levels, there is a huge gap between the capital city of Prague and other regions. The average wages in other regions are below the average of the Czech Republic except for the Středočeský Region (in 2013-2015). In the observed period, the average wages in the Czech Republic were growing, with the exception of 2013, when the average wages in Prague, the Zlín, Olomoucký and Královéhradecký Regions were decreasing.

The average wage in the capital city of Prague increased from CZK 26,896 in 2007 up to CZK 32,715 in 2015, but a drop of CZK 987 was recorded in 2013. In the period reviewed, the lowest average wages were in the Karlovy Vary region (2007: 17,448 EUR, 2015: 21,949 CZK).

Average wages in CR had increased most markedly in the pre-crisis period - in 2008, when the average growth rate reached $7.86 \%$, in the Královéhradecký Region they increased even by $9.02 \%$. In the following years, the wage growth was slower, in 2013 the average wages in the Czech Republic decreased by CZK 80 , respectively by $0.33 \%$. The wage growth was accelerating in 2014 and 2015.

\subsection{The comparison of average monthly wage evolution in the regions of Slovakia and the Czech Republic}

Differences within the level of average monthly wage in the regions of Slovakia and the Czech Republic are evaluated by using the variation coefficient and the growth rate of wages, when comparing its minimum, maximum and average values. These values are shown in Table 2. 
Tab. 2 - The comparison of average wage development in SR and CR regions. Source: own calculations

\begin{tabular}{|c|c|c|c|c|c|c|c|c|c|c|}
\hline \multirow{2}{*}{\multicolumn{2}{|c|}{ Slovak Republic }} & 2007 & 2008 & 2009 & 2010 & 2011 & 2012 & 2013 & 2014 & 2015 \\
\hline & & & & & & & & & & \\
\hline \multicolumn{2}{|c|}{ variation coefficient } & 16.01 & 15.58 & 15.51 & 15.00 & 14.29 & 14.60 & 14.18 & 14.92 & 14.05 \\
\hline \multirow{3}{*}{$\begin{array}{l}\text { growth } \\
\text { rate }\end{array}$} & $\min$. & - & 6.29 & 0.79 & 1.76 & 1.01 & -0.15 & 0.83 & 2.24 & 1.36 \\
\hline & $\max$. & - & 9.98 & 4.95 & 4.96 & 4.57 & 5.39 & 4.59 & 5.53 & 4.80 \\
\hline & average & - & 8.07 & 3.04 & 3.22 & 2.21 & 2.42 & 2.36 & 4.13 & 2.91 \\
\hline \multicolumn{11}{|c|}{ Czech Republic } \\
\hline \multicolumn{2}{|c|}{ variation coefficient } & 10.97 & 10.94 & 11.30 & 11.63 & 11.22 & 10.94 & 10.02 & 9.99 & 9.87 \\
\hline \multirow{3}{*}{$\begin{array}{l}\text { growth } \\
\text { rate }\end{array}$} & $\min$. & - & 6.54 & 0.97 & 0.57 & 0.76 & 1.14 & -3.10 & 1.92 & 2.68 \\
\hline & $\max$. & - & 9.02 & 5.28 & 3.10 & 4.21 & 3.78 & 1.22 & 4.06 & $4, .02$ \\
\hline & average & - & 7.86 & 3.34 & 2.03 & 2.21 & 2.59 & -0.33 & 2.99 & 3.23 \\
\hline
\end{tabular}

The variation coefficient expresses the relative variability of average monthly wage in the regions of SR and CR. Throughout the observed period, the variation coefficient of an average wage was higher in the Slovak Republic. The largest difference between SR and the Czech Republic was in 2007, up to 5.04 p.p. The smallest differences in variability were in 2011. These figures are shown in Figure 6.

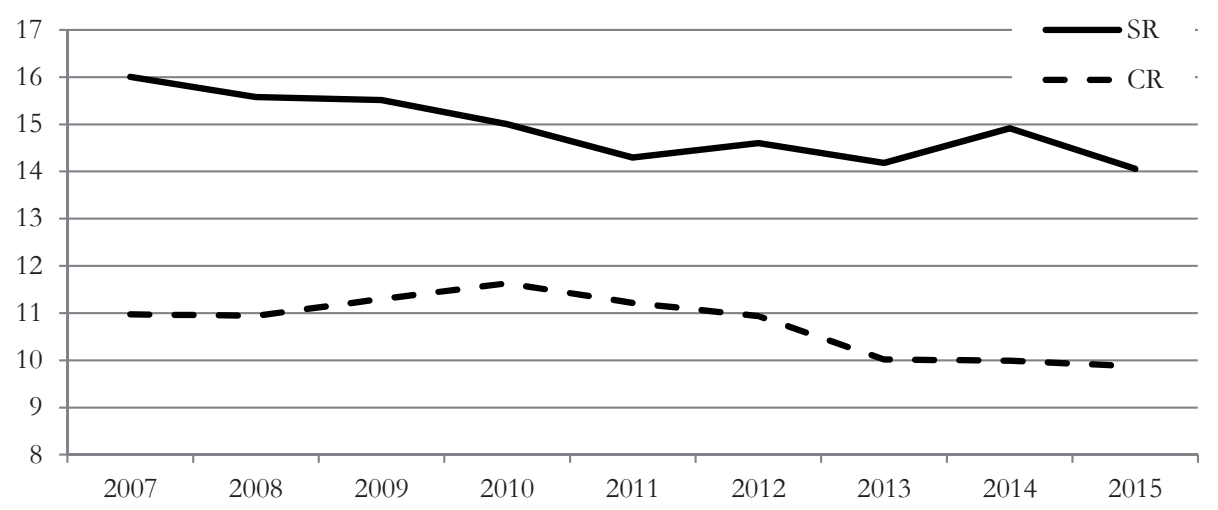

Fig. 6 - The variation coefficient of average monthly wage in SR and CR. Source: own processing, own calculations

Table 2 shows the growth rate values of average monthly wage. The data in the table show that both in Slovakia and the Czech Republic, a high growth rate of monthly wage was observed in 2008, the maximum growth rate in 2008 was higher in Slovakia $-9.98 \%$. In both countries, the wage growth was slower in the following years. In the Czech Republic, there was a drop in wages in 2013. In 2014 and 2015, the average wages were growing faster in Slovakia. This is illustrated in Figure 7. 


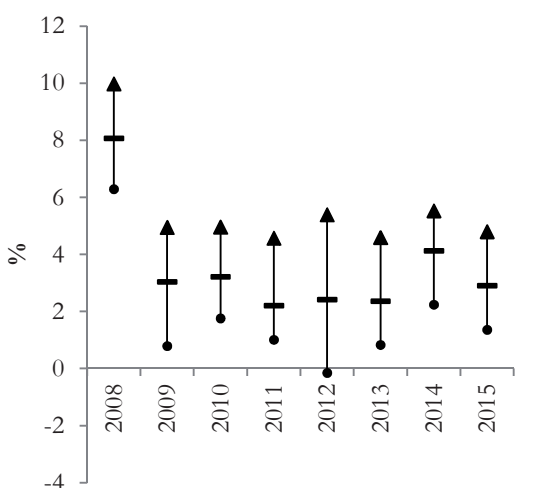

Slovak Republic

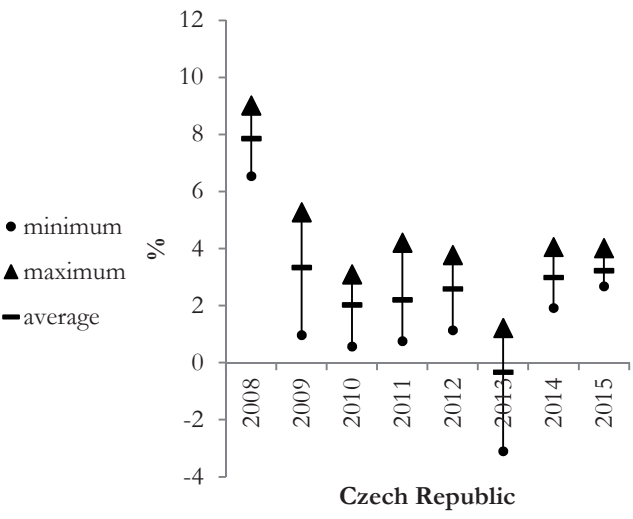

Czech Republic

Fig. 7 - Minimum, maximum and average growth rates of wages in SR and the Czech Republic. Source: own processing, own calculations

\section{CONCLUSIONS}

In the labour market, there is the most precious capital of every economy - human capital, which is also the carrier of work. According to Ivanová (2010), labour market is sensitive to changes that can occur within the economy of a particular country, and to the processes taking place within the world economy due to the deepening process of international division of labour. The labour market development in Slovakia and the Czech Republic was affected mainly by changes occurring during the transformation of economies, accession to European Union and also global economic crisis. These factors also affected the development of employment indicators and average monthly wage, which were also the object of our research.

From the results of the analyses, significant regional differences can be observed both in the labour market of Slovakia and the Czech Republic due to the different primary potentials (location and natural conditions), different possibilities of development (natural resources, tourism), economic structure (industries), demographic differences and the levels of infrastructure.

Regarding the employment rate, in Slovak regions, it ranges from $45 \%$ to $63 \%$, with the highest values in 2008. In the Czech Republic, the lowest values are about 50\%, the highest about $61 \%$. Within the level of employment in the Slovak Republic, the variation is significantly higher in comparison with the one in the Czech Republic, but from 2012, the differences between regions are gradually decreasing. The highest employment rate was achieved by regions with the capital city (Bratislava Region, Prague). As for the average monthly wage, the gap between regions with their capital cities and other regions is even more distinctive. The average monthly wage variation is again higher in SR. On the other hand, the growth rate of average wages is higher in SR.

To sum up, the situation in the Czech labour market is better than in the Slovak Republic, and the differences among regions are smaller in CR. 
However, it should be noted that Slovak economy is experiencing favourable economic conditions and at present, it is possible to observe an increasing number of jobs creation, which is also reflected in the outflow of unemployed people from labour offices. The continued growth of economy creates an increasing demand for labour, and we can already see that in some professions, there is a problem to fill job positions, resulting in the pressure on nominal wage rising. Also, the Czech Republic is experiencing favourable economic conditions where it is assumed that employment would continue to raise along with wages. This is mainly due to a better situation in the labour market, which is reflected in the increasing employment and accelerating growth rate of wages.

\section{Acknowledgment}

The paper is an outcome of the project VEGA 1/0233/16, "Dimensions and Factors Related to Social and Economic Development of V4 Regions".

\section{References}

1. Androniceanu, A. \& Ohanyan, G. (2016). Comparative approach on education and healthcare in Romania and Bulgaria as beneficiaries of the IMF financial assistance. Administratie si Management Public, 2016 (26), 25-48.

2. Baštová, M. \& Dokoupil, J. (2010). Negativní dopady př́ímých zahraničních investic na trh práce města Plzně. Geografie - sborník Ceské geografické společnosti, 115 (2), 188-206.

3. Bezák, A. (2001). O regionálnych trhoch práce, nových krajoch a tokoch nezamestnaných. Geografický časopis, 53 (4), 295-305.

4. Blecker, R., A. (2016). Wage-led versus profit-led demand regimes: the long and the short of it. Review of Keynesian Economics, 4 (4), 373-390. Retrieved from https://www.elgaronline. com/search?f_0 $=$ author\&q_0 $=$ Robert + A.+Blecker.

5. Bratianu, C., \& Anagnoste, S. (2011). The role of transformational leadership in mergers and acquisitions in emergent economies. Management \& Marketing. Challenges for the Knowledge Society, 6(2), 319-326.

6. Cyrek, M. (2017). Social efficiency of employment in three sectors - a comparison of Polish regions. Equilibrium. Quarterly Journal of Economics and Economic Policy, 12(3), 417-432. https://doi.org/10.24136/eq.v12i3.22.

7. Dolobáč, M. (2013). Regulácia odmeny za prácu ako nástroj vyrovnávania regionálnych rozdielov. Tvorba a realizácia pracounébo práva so żretelom na regionálne aspekty trbu práce. Košice: Univerzita Pavla Jozefa Šafárika.

8. Dragolea, L., Grondys, K., \& Sroka, M. (2017). Career management: Short analysis regarding interest on employment fields among youths. Polish Journal of Management Studies, 16 (2), 62-73.

9. Gavurova, B., Soltes, M., \& Kovac, V. (2017). Application of cluster analysis in process of competitiveness modelling of Slovak Republic regions. Transformations in Business \& Economics, 16(3), 129-147.

10. Grenčíková, A. \& Španková, J. (2016). Labour Migration Trends in the Slovak Republic. Economics and Sociology, 9(2), 158-167. 
11. Cheba, K., \& Szopik-Depczyńska, K. (2017). Multidimensional comparative analysis of the competitive capacity of the European Union countries and geographical regions. Oeconomia Copernicana, 8(4), 487-504. https://doi.org/10.24136/oc.v8i4.30.

12. Ivanová et al. (2006). Ekonomická teória. Základy ekonómie. Trenčín: FSEV Alexander Dubček University of Trenčín.

13. Ivanová, E. (2010). Vplyv globálnej hospodárskej krízy na trh práce v SR. Sociálnoekonomická revue, 8 (3), 22-26.

14. Krajňáková, E. (2014). Sociálne aspekty investovania do l’udského kapitálu. Sociálnoekonomická revue, 12 (1), 38-47.

15. Komárek, T. M. (2016). Labour market dynamics and the unconventional natural gas boom: Evidence from the Marcellus region. Resource and Energy Economics, 45, 1-17. https:// doi.org/10.1016/j.reseneeco.2016.03.004.

16. Kordoš, M. \& Vojtovič, S. (2016). Transnational corporations in the global world economic environment. Procedia - Social and Behavioral Sciences, 230(1), 150-158. https://doi.org/10.1016/ j.sbspro.2016.09.019.

17. Měrtlová, L. (2012). Porovnáni regionálních disparit v regionech Ceské republiky. XV. męinárodní kolokvium o regionálních védách. Brno: Masaryk University.

18. Michálek, A. (2010). Social Inequalities and Poverty in Slovakia: Regional analysis of incomes, Wages and Poverty. Sociálny kapitál, ludský kapitál a chudoba v regiónoch Slovenska. Košice: Technical University.

19. Ohanyan G. \& Androniceanu, A. (2017). Evaluation of IMF program effects on employment in the EU. Acta Oeconomica, 67(3), 311-332.

20. Pauhofová, I. (2010). Regional income stratification of the population in Slovakia. Sociálny kapitál, l’udský kapitál a chudoba v regiónoch Slovenska. Košice: Technical University.

21. Pavlova, I. \& Šenfelde, M. (2017). The impact on the population on the sustainable urban economic development. Entrepreneurship and Sustainability Issues, 5(2), 330-344. https://doi. org $/ 10.9770 /$ jesi.2017.5.2(12).

22. Păunescu, C., Gilmeanu, D., \& Găucă, O. (2017). Examining obligations to society for QS Stars best ranked universities in social responsibility. Management \& Marketing. Challenges for the Knowledge Society, 12(4), 551-570. https://doi.org/10.1515/mmcks-2017-0033.

23. Pernica, M. (2017). The business impact analysis of the Minimum Wage valorization. Business: Theory and Practice, 18: 88-95. DOI: 10.3846/btp.2017.010.

24. Pietrzak, M. B., Balcerzak, A. P., Gajdos, A., \& Arendt, L. (2017). Entrepreneurial environment at regional level: the case of Polish path towards sustainable socio-economic development. Entrepreneurship and Sustainability Issues, 5(2), 190-203. https://doi.org/10.9770/ jesi.2017.5.2(2).

25. Sanusi, K.A., Meyer, D., \& Ślusarczyk, B. (2017). The relationship between changes in inflation and financial development. Polish Journal of Management Studies, 16 (2), 253-265.

26. Svatošová, L. \& Novotná, Z. 2012. Regionální disparity a jejich vývoj v ČR v letech 19962010. Acta Universitatis Bohemiae Meridionales, 15 (1), 103-110. 
27. Simionescu, M., Ciuiu, D., Bilan, Y., \& Strielkowski, W. (2016). GDP and net migration in some eastern and south-eastern countries of Europe. A panel data and Bayesian approach. Montenegrin Journal of Economics, 12(2), 161-172.

28. Stacho, Z., Stachova, K., Hudakova, M., \& Stasiak-Betlejewska, R. (2017), Employee adaption as key activity in human resource management upon implementing and maintaining desired organizational culture. Serbian Journal of Management, 12(2), 305-315.

29. Székely, V. (2001). Časovo-priestorová diferenciácia nezamestnanosti a jej tokov na Slovensku v rokoch 1997-1999. Geografické časopis, 53 (1), 147-170.

30. Vancea, M. \& Utzet, M. (2017). How unemployment and precarious employment affect the health of young people: A scoping study on social determinants. Scandinavian Journal of Public Health, 45 (1), 73-84. https://doi.org/10.1177/1403494816679555.

31. Statistical Office of the SR. (2018). Statistics of the SR. Retrieved from https://www. statistics.sk.

32. Czech Statistical Office. (2018) Statistics of the Czech Republic. Retrieved from https:// www.czso.cz.

\section{Contact information}

Ing. Eva Koisova, PhD.

Alexander Dubreke. University of Trencín

Faculty of Social and Economic Relations

Department of Economy and Economics

Slovakia

E-mail:eva.koisova@tnuni.sk

Ing. Jana Masarova, PhD.

Alexander Dubcele University of Trencín

Faculty of Social and Economic Relations

Department of Economy and Economics

Slovakia

E-mail:jana.masarova@tnuni.sk

Doc. Ing. Jozef Habanik, PhD.

Alexander Dubrék University of Trenčin

Faculty of Social and Economic Relations

Department of Economy and Economics

Slovakia

E-mail:jozef.babanik@tnuni.sk 